\title{
Ethnic Entrepreneurs and Other Migrants in the Wake of Globalization
}

Aleksandra Ålund

The self-archived postprint version of this journal article is available at Linköping University Institutional Repository (DiVA):

http:/ / urn.kb.se/ resolve?urn=urn:nbn:se:liu:diva-46717

N.B.: When citing this work, cite the original publication.

This is an electronic version of an article published in:

Ålund, A., (2003), Ethnic Entrepreneurs and Other Migrants in the Wake of Globalization,

International Review of Sociology, 13(1), 77-87. https:// doi.org/ 10.1080/ 0390670032000086998

Original publication available at:

https:/ / doi.org/ 10.1080/ 0390670032000086998

Copyright: Taylor \& Francis (Routledge) (SSH Titles)

http:// www.routledge.com/ 
Draft: Ålund, A. (2003) "Ethnic entrepreneurs and other Migrants in the Wake of Globalisation". International Review of Sociology, Vol 13, No 1 pp. 7787.

\title{
Ethnic Entrepreneurs and Other Migrants in the Wake of Globalisation
}

\author{
Aleksandra Alund, REMESO, University of Linköping, \\ Sweden
}

\section{Abstract}

This article offers a reflection on migration in the era of globalisation, and on its expression in contexts of tourism and self-employment. Ethnic

entrepreneurship is increasing in Sweden. The motive forces behind this kind of self-employment are discussed in relation to unemployment and discrimination in the Swedish labour market. Other aspects of entrepreneurship to be discussed are related to the "importation" of Thais as "tourists" to Sweden, where they are exposed to severe exploitation in the informal economy. Different expressions of ethnic entrepreneurship are discussed in the context of the "global city" and its various types of citizen. 
Ethnic entrepreneurship has often been portrayed in terms of success stories, e.g. with regard to the Jewish immigrants who founded Hollywood's film industry or to Asian control over the garment industry in Britain. But economic insecurity and social exclusion are also part of the experience of ethnic entrepreneurship.

Ethnic entrepreneurship is perhaps the current phenomenon that most closely reflects the contrasting light and dark sides of the globalised world. In Sweden we have seen evidence of many new kinds of ethnic businesses emerging. Exotic food and a sophisticated supply of other "multicultural" services are expected to exist everywhere in order to satisfy the needs of transnational business leaders, experts and other "global tourists". But we have also seen Thai so-called "tourists" imported to Sweden being exposed to serious exploitation in the informal economy. This trade is managed by certain "ethnic entrepreneurs", who constitute a particular variant of what have become known as “transnational communities".

Self-employment, tourism and global migration appear to have more points of contact than one would at first think. An article in the Swedish daily Dagens Nyheter (May 19, 2000) illustrates this in a striking manner. It concerns the "stream of refugees over the Straits of Gibraltar", the role of Spain as the EU's border-guard to Africa and the extensive illegal immigration of poor people from the south. We are here faced with "a human tragedy taking place in silence", intimately interconnected with the expanding leisure industry and tourism.

The journalist Dan Jönsson describes how the idyllic and whitewashed scenery of Andalusia is filled with immigrant "tourists", northern and western 
Europeans who in ever-increasing numbers have chosen to take up permanent residence in sunny Spain. To all appearances, they continue to live a touristic existence: The gentlemen "spend their days on one of the coast's forty golf courses", while the ladies "can relieve their boredom at The Costa del Sol Flower-arranging Club".

Yet in recent times this idyllic setting has been marred by a series of violent riots. To the long-term or residential tourists in the area, in whose guide books the native population is described as "tolerant and easy-going", this may have come as a surprise. For the Moroccan illegal labourers, however, who form the service troops of the tourist economy and who have been the primary victims of the riots, "it probably doesn't”, Jönsson points out.

Jönsson discusses how racial violence has gradually increased in Spain; how the mayor of El Ejido ordered the demolition of the shantytown where the Moroccans live, and how at the end of the nineties "pogrom-like outbreaks" developed and "an increasingly well-organised extreme right" evolved, with the "neo-falangist FE-FNS" as the most militant grouping. Jönsson fears that the EU is about to "Americanise itself" toward a "gated community," with well-off golf enthusiasts on one side of the fence, and the "poor of the south", kept behind a well-guarded border, on the other.

How does this tally with the openness; the flow of information, goods and services; the cultural cross-fertilisation and so on that one so often reads about in connection with the globalised world? Or are they opposite sides of the same coin? After all, rich tourists need poor, often illegal, labourers for all the services they want to have available at the lowest possible cost. However, this explanation is not quite adequate in view of the extremely complex conditions 
that characterise current labour market relations. These are distinguished by the appearance of a new sort of complementarity in the wake of the expansive development, particularly in the IT and financial services areas.

Analysing ethnic entrepreneurship in the context of the economy of the global city, Roger Waldinger (1996) argues that the post-industrial labour market simultaneously generates high-level professional and managerial jobs and a proliferation of low-skilled, low-income service jobs. This means that "the polarised metropolis leaves minorities far from useless; instead they serve as the new drawers of water and hewers of wood". In this connection the relationship is such that "it is not the poor who depend on the rich for their beneficence or for jobs and income to trickle down. Rather, the rich need the poor - to provide low-cost services, to maintain the city's underbelly, and to prop up what remains of the depressed manufacturing sector" (Waldinger 1996:2).

New economic niches develop within a framework of complex needs generated by the city's new global information and finance companies and its professional elite: jet-set travellers who often enough are also tourists, in a sense, travelling between the urban nodes of the new, interlaced global market. The supply of multicultural services should be as international in Stockholm as it is in London, Paris or New York. This is also where global migrants come in - as labourers, entrepreneurs or, as in Spain, illegal immigrants. 


\section{Migration in the Era of Globalisation}

Various processes, often subsumed under the collective term 'globalisation', have caused "near" and "far" to become interlaced, and networks of human contacts to become expanded and packed. The nearby social relations of local life have been meshed with faraway events and global connections (cf. Giddens. 1991).

Globalisation is, in a cultural as well as economic sense, a key term for understanding today's strongly increasing movement in population. In the European context, it has to do with various kinds of immigration and the meaning this has had for Sweden and other economically developed countries in Europe, but also with crisis areas in "the other Europe" (the formerly communist countries). It concerns both labour migrations - probably once again on the increase - and refugee migration: from east to west and from south to north. We truly live in an "age of migration" (Castles and Miller 1993).

The integration of the global economy and the global cultural context have caused new problems to arise. Issues of ethnicity and ethnic relations have become more topical than ever, as have questions of multiculturalism, nationalism and racism. These issues have become central societal concerns and have placed ethnicity at the focus of public debate and politics. Identity, language and culture, but also such factors as tourism become especially important in the context of new ethnic minorities in society. All too often, however, these questions are discussed independently of the concrete material and social conditions of life. Today's globalised society has to a large extent 
become characterised by a split along ethnic lines, as well as by urban segregation and social marginalisation. These developments have contributed to the fact that in Swedish society, two kinds of citizens have emerged: those who are Swedes and those who are forever immigrants.

Global migrants have sometimes been called the "new Helots", or new slaves (Cohen 1987), exemplified by the increasing populations of maids and nannies, who, without any legal rights, are compelled to emigrate in their thousands from the Third World to rich families in the US, Hong Kong, Europe, and so on. A re-traditionalisation of the service sector tends to create new social and cultural differences and new forms of ethnification, especially of vulnerable people and groups. Social or cultural exclusion and discrimination can also lead to ethnic mobilisation, which can in itself be an important symbolic platform for political mobilisation, where "the cultural resources of ethnicity can stand for solidarity in the political struggle" (Rex 1995:23). However, against the background of grave social evils, ethnic mobilisation can also be expressed in isolationism and reverse exclusion, such as regressive (re-)traditionalisation of social relations between individuals and groups (Ålund 1991 and 1997).

The social inequality of the global multicultural society has become striking, and the social dimensions of cultural fragmentation have achieved topicality value in research on immigration and ethnic relations. The connections between the spread of poverty and the disintegration of the welfare state, as well as the intertwining of social, cultural and identity processes, have received even more attention in the international academic debate. Ethnicity is increasingly associated with varying conditions for societal membership in terms of social fairness, political participation and other aspects of citizenship status and 
conditions for citizenship (Turner 1990). The issues of "inclusion" and "exclusion" are central here. Concretely, this can express itself in temporary protection for refugees, temporary work permits, political exclusion and discrimination that affect migrants in the EU and globally.

An extensive international debate among social scientists has underlined the central importance of citizenship. Citizenship defines the individual's relation to the state and the basic conditions for attaining a position in society. It includes formal juridical and cultural-ideological as well as substantial material aspects in the form of real possibilities for political participation, social membership, cultural realisation and economic participation. How a society defines citizenship rights juridico-politically and creates conditions for its practical realisation in the social, political, and cultural senses are decisive for the possibilities for the development of a multicultural understanding capable of bridging the ethnic divisions in modern society. The concept of citizenship is central to today's discussion about the future of the multinational and multiethnic European Union. New terms, such as "transnational" and "postnational" citizenship point to new questions, not least concerning the changed meaning of national citizenship in a legal, political and cultural sense. One must, to an ever-greater degree, relate to the obvious problems we face today concerning social exclusion among large groups of EU “citizens".

The uneven development of modern society, with its polarisations of resource distribution and of economical and political power, creates global, national and local hierarchies. These are embedded in and themselves condition processes that affect migration, segregation and social conflicts. 
An important aspect of globalisation is connected to transnational enterprising and to the new division of labour associated with it. Transnational enterprising is, in turn, related to the development of diverse service sectors and the recruitment of specialists within various areas; professionals in everything from hardware to software, research, industrial operations and service of various kinds. Many of the specialists in the service sector seem to be immigrants, and processes of social exclusion and marginalisation appear to contribute to their being constrained to its lower eschelons. "More or less permanent high levels of unemployment are pushing an increasing number of immigrants towards entrepreneurship" (Kloosterman, van der Leun and Rath 1998:249). The science parks and IT empires developing in today's metropoli require their "multicultural" environments for entertainment and services; a new globalised city environment which also often constitutes a polarised world of poor and rich, legal and clandestine immigrants, and "tourists": the included and the excluded.

In the countryside, too, we encounter various kinds of modern tourists: those seeking clean air and untouched nature as well as those who, more or less involuntarily, are forced to "enjoy" clean and unspoiled expanses of forest. In the following I shall draw some sketches of the multicultural stock of the city and the forest, which the trail of migration has led here, close to the Arctic Circle. City and forest have, it appears, a number of connecting links. Often, the lustre of the multicultural also turns out to be corroded by the sweat of "sweatshops" in the forest as well as in the city. 


\section{Berry-picking Tourists and Other More or Less}

\section{Stray Visitors to Sweden}

Picking berries in Sweden has become something of a global enterprise.

During the summer, when my husband and I went to pick strawberries in the interior of the northern Swedish province of Västerbotten, we came across several "tourists" from Southeast Asia who had already cleared the sparse rows of strawberries on an out-of-the-way pick-them-yourself field. It was evening and raining and after the first picked litre, we decided to buy some of the sorted boxes of strawberries that the cheap labour from afar had already filled. The price was minimally higher than if one had done the job oneself, and not having to get cold and wet was included in the bargain. I took the opportunity and asked a young Thai woman how she had come to rainy Västerbotten to pick berries. It turned out that she was a student and that, unlike the others in the group, she had not thought she was going to pick oranges in a hot country. She had also known that in order to save anything out of the poor pay, she would have nothing but a bowl of rice a day, mixed with tinned food from home. But she wanted to see Sweden, and the "organiser" paid for the trip. Poor living conditions and the lack of berries this rainy summer created a lot of problems for this "organiser". Several Thai people have been found in the cold Swedish forest, sick and hungry, and have been sent back to Thailand. To start with, all of them were "tourists" in Sweden, a land in which those designated by the term are not expected to be poor or Thai. They, however, represent one aspect of the complex interrelationship between globalisation, transnational community networks and the informal economy. 
The informal economy is becoming an integrated part of the post-industrial economy, reflecting the economic hierarchies of contemporary global world: on the one hand, "processes of marginalisation and exclusion on the formal labour market"; on the other, "the economic significance of human capital and social networks based on ethnicity" (Kloosterman, van der Leun and Rath 1998:250). Drawing on extensive discussion and references, Kloosterman et al. (1998) argue that the informal economy, rather than being illegal, is a kind of practice that escapes legal regulation, thereby exposing a lack of governmental control (i.e. in this case, the function of "tourists" as undocumented workers). In this way, "the difference between informal economic activities and criminal activities is not always easy to ascertain" (Ibid. 253).

Development towards informal as well as formal economic activities in the area of ethnic etrepreneurship is, as has been mentioned above, related to the structure of the post-industial economy, marginalisation, social exclusion and unemployment among immigrants. These factors result in the latters' low rate of participation in the formal labour market and channel them towards selfemployment in the sphere of the "ethnic labour market". While these processes are usually related to and described in the context of development in advanced urban economies, I will turn below to some examples of ethnic entrepreneurship on the periphery; namely, in the Swedish forest.

The deep forests of Sweden also play host to a number of entrepreneurs with roots in the labour and refugee migrations and their spread across the country. These offer, among other things, exotic food services. An Australian couple, visiting researchers at Umeå University (in the province of Västerbotten) at the end of the nineties, took a tourist trip to Lycksele, a little town in the same 
northern province. When going out for dinner in the evening, they were faced with a choice between a local food restaurant and a pizza restaurant with an Italian name. One of the couple, being herself of Italian heritage, chose the pizza alternative. When she spoke to the host in Italian, he answered in English. He was from the Middle East and had opened the pizza restaurant when, after completing his studies in Sweden, he could not secure a job in his profession.

Many Iranians in this remote part of Sweden have found occupations in the pizza trade; they have become self-employed, starting or taking over pizza restaurants, as a consequence of not finding work commensurate with the education they have received for example the University of Umeå. Umeå is known for having Sweden's best-educated cleaners, at least among those who work at the university itself and at the University Hospital. I myself have met many of these scholars, educated at Umeå University, who have not been able to get any other job. This aspect of compulsion is seldom mentioned in today's increasingly positively charged Swedish debate about immigrants and ethnic businesses.

Obviously, there are many entrepreneurs among immigrants who were pleased and stimulated when, during the nineties, the Swedish government started showing a more positive attitude towards self-employment and especially called attention to the need for making it easier for newly established enterprises. But, as we shall see later, many among those who have started their own businesses were previously long-term unemployed. Self-employment has for these people been one of the few possible ways out of the unemployment which, during the nineties, subjected immigrants as a group particularly hard. Being grouped as immigrants and therefore placed on the periphery of social, 
cultural and economic life at the same time results in discrimination against Swedish citizens of foreign birth as well as their children, most of whom were born and raised in Sweden. A co-operative for unemployed women with immigrant backgrounds in a suburb of Stockholm can serve as an illustration of how this ethnic categorisation affects individual carrier possibilities as well as the position of "immigrants" in the societal division of labour.

A few years ago these women started a catering firm to provide multicultural food in the environment of an internationally oriented business complex. I met the women in connection with a conference related to my engagement with TSER project on "Self-employment"1, at a dinner for the conference participants. Besides getting to partake of the delicious food, I also found the opportunity to talk to one of the women. She was a teacher from Iran and, as an educated woman of the Iranian middle class, she was not happy about the fact that she was now working in catering. She had never thought that she would end up here in this suburb, cooking. She had always been able to cook, but as a middle-class girl she had grown up in a home where maids did the cooking while she was being prepared for well-educated professional work, a path that for her ended when the Mullahs took over in Iran. She then came to Sweden. The other women in the co-operative also turned out to have some kind of professional training, including academic. Being both women and immigrants, it had been more or less taken for granted by the local authorities that they were good at cooking exotic food. The food was indeed very good, but it was not certain that any of these women had the option of choosing to do something

$\mathbf{1}$.TSER project on Self-employment activities concerning women and minorities: their success or failure in relation to social citizenship policies, 
else. None of them seemed especially enthusiastic about cooking professionally in Sweden. 2

The local government bureaucracy, which had encouraged the venture and which had supported the co-operative with all sorts of professional training as well as with mentor contacts, also had problems. One had to do with the problem of learning Swedish. It had been assumed that a multiethnic group of "immigrant women" would learn the language easier than if they all came from the same country. But none of the women was especially good at Swedish to start with and the catering work took up all of their time; there wasn't much left over for language training. The women also had difficulties "mastering" the local bureaucracy. Quite simply, the "business" was in trouble, perhaps essentially because the women were not particularly motivated either to cook or to be self-employed. In a certain sense, the local bureaucracy had in this case reduced a cultural multiplicity to a basic service: the provision of exotic food. What one has to realise is that ethnic enterprising has many dimensions and that "immigrants" do not automatically want to be self-employed or even work in the service industry.

\section{The Bazaar as Culture and Culture as a Bazaar}

In Sweden it is not unusual for "immigrants" to be defined, categorised and bunched together as especially suitable for certain tasks and as unsuitable for others. It is also not unusual, when some "immigrant" behaviour is considered deviant by the majority society, for explanations to be sought in the realm of "culture"; in such explanations immigrants are often stereotyped as being

2 See also the article by Suzanne Mason in this volume. 
traditionalists in one sense or another. The notion of "their culture" is often used indiscriminately, and problems that are obviously of social origin tend to be defined as cultural ones.

Swedish researcher Woukko Knocke has described how representatives from a local union and employers at a work place in Sweden claimed that women from a certain country were more often ill due to having "something special in their blood" (Knocke 1991:11). They were, according to Knocke, considered to be culturally programmed in a certain direction. The health problems were explained as culturally conditioned, instead of conditioned by the work environment in question.

Culturalised understandings also appear within research. Static understandings of culture as something "given" or "inherited" are taken as the starting point for scientific perspectives and for explanations of why Turks, for instance, being born into an extensive bazaar culture, are assumed to be especially suitable as small dealers and as self-employed (Hjarnö, 1987).

In a critique of the research on ethnic entrepreneurship, Pnina Werbner (1999) claims that much of the understanding of which ethnic groups have succeeded or failed has been lost due to such limited approaches that build on simplified stereotypical assumptions, static views of culture and a lack of longterm follow-ups.

At the same time, she tends towards a view and understanding of culture as being almost like a human bazaar, filled with possibilities and constant adjustments to the demands and wants and possibilities of the outside world. Ethnic entrepreneurs are seen as representatives of inventive people who constantly find new commercial niches to fill. "Ethnic groups" invent a sector of 
their own and, with the help of their well-organised networks, they eventually take control of certain economic niches ("ethnic enclave economies"), sometimes called "ethnic niches" (Werbner 1999).

The impression one gets is that there is a potential bazaar merchant in every immigrant. It is almost as if anybody could succeed. However, what is overlooked in the analysis is the aspect of compulsion involved in starting one's own business, a compulsion that isn't always apparent when one first meets the entrepreneur in question in his "shop full of dreams" (Collins et al. 1995). The dream might have been of becoming a clerk, a physician, or a computer engineer, and not necessarily that which one was forced to become: namely selfemployed (cf. Ålund 1991).

Among others, Roger Waldinger (1996) presents a critical view of the ethnic hierarchisation in the American labour market and points to areas where especially African-Americans appear to have been left out. Different ethnic groups replace one another on the ascending scale of social mobility. AfricanAmericans, however, can't quite get a foothold in the labour market, due, according to Waldinger, to racism and discrimination. Werbner considers this type of research to be far too much governed by the use of quantitative methods and a structural perspective, as a result of which qualitative, time and especially cultural aspects are neglected.

When, for instance, Waldinger focusses on the exclusion of AfricanAmericans, Werbner instead emphasises their having carved out the hip-hop music sector as their niche. Yet the question is if one really can speak of African-Americans as an "ethnic group", and how large a proportion have "succeeded" and prospered in the hip-hop music business. 
In Sweden, the dimension of compulsion in self-employment is conspicuous. A well-informed researcher in the field, Ali Najib, points out that many of the ethnic entrepreneurs have previously been unemployed: $29 \%$ in 1993 and $25 \%$ in 1995 (Najib 1995). Among immigrants, starting one's own business became an expanding trend during the $1990 \mathrm{~s}$, and both discrimination in the labour market and the marginalisation of educated immigrants have without a doubt been motive forces towards self-employment. Or as Najib has put it, “...it is simply necessary in order to cope" (Najib, 1995).

Today self-employed entrepreneurs make up approximately $18 \%$ of all working immigrants in Sweden, and small immigrant businesses constitute some $12 \%$ of all small businesses (Najib 1999). In this, it is important to note that the small, private firm is the most common form, with a small turnover and few employees (Najib 1999). Immigrants have usually bought small Swedish firms that were on their way down, and have thus in certain branches have brought the wheels of the economy in motion again, Najib points out.

The expansion of ethnic entrepreneurship took place during the nineties, a time of widespread unemployment, especially for immigrants, on the Swedish labour market. The most obvious reason behind this expansion seems to have been difficulties in getting employment. During 1999 I carried out a number of interviews with labour market representatives of the district administrations in the multiethnic Stockholm suburbs of Spånga-Tensta, Kista and Rinkeby. Selfemployment was considered the way out of exclusion for unemployed immigrants. Stockholm has become characterised by a pronounced polarisation between Swedes and immigrants in terms of housing and employment. 


\section{The Global City}

The multiple expressions of globalisation can be described as tendencies toward economic polarisation and the development of social inequalities (Sassen 1996:2). The effects of the global economy are concentrated in the multiethnic city, and are expressed through a new geography of centrality and marginality. This new geography "is the outcome of the current forms of economic growth" (ibid.), where global processes are localised in terms of the concentration of economic power and influence in powerful business centres with international ramifications. The dark side of this process is the development of urban low-income areas, which, when deprived of various resources, encourage the development of marginality and, in the long term, the reproduction of existing inequalities.

While the dominant research on globalisation tends to focus on the rise of an international class of new professional élites, the latter aspect - the internationalisation of a low-income sector of manual and service sector work, in which economic growth has been fuelled largely by immigration - has not received the same degree of attention. The concentration of economic power in new global centres has as its antipode in the impoverishment of various sorts of marginalised peripheries; urban and regional areas marked by increased racialisation and a segmentation of the labour market (Sassen 1996:3).

When globalisation is understood in this way, as a set of different processes through which the global is localised, the tendencies towards complexity and polarisation in the current international labour market are also made clear. Poverty and exclusion are found side by side with wealth and power. The 
polarisation and racialisation of the labour market form the basis for a new economic regime, which represents fundamental aspects of globalisation.

The social fragmentation of the global city and the segmentation of the urban economy accordingly express "the expansion of a high-income work force in conjunction with the emergence of new cultural forms" which has led to a "high-income gentrification that rests, in the last analysis, on the availability of a vast supply of low-wage workers" (Sassen 1996:5). This new economy, with its centre-periphery geography, has both strengthened existing inequalities and given rise to the development of a new dynamic of inequality. Seen from this perspective, the city constitutes a strategic terrain for a whole series of conflicts and contradictions (ibid.).

This kind of development is noticeable in Sweden as well. Here unemployment in urban areas, especially among immigrants, has attracted attention. One can clearly observe an increasing split between Swedes and immigrants in terms of both housing and work. The immigrants were much more severely affected by the economic crisis and unemployment of the 1990 s than ethnic Swedes, which can be seen most clearly in the urban environments and areas with high immigrant populations. During the period 1990-95, for example, unemployment doubled among immigrants in Fittja and Rinkeby, two of the better known "immigrant-dense" suburbs of Stockholm (Bengtsson 1999).

Various studies in Sweden indicate that ethnic belonging has become decisive for one's chances of getting a job. Trends in the labour market increasingly indicate a categorisation of people along ethnic lines; they point to discrimination and to the appearance of an "ethnic division of labour" (Schierup and Paulson, 1994). Immigrants who have taken a degree in Sweden have lower 
incomes than Swedes with the same degree (Wadensjö, 1995:3). Well-qualified immigrants who had lived in Sweden since the sixties were, in the eighties, in jobs below their educational level (Ålund, 1997). Other studies suggest that the subordinate status persists for "second-generation" immigrants (Schierup and Paulson, 1994): On average, the children of labour migrants suffer more unemployment than Swedish youth of the same age (Leiniö, 1994).

Polarisation and the development of a split society seem to have accelerated during the nineties. That decade witnessed a dramatic decrease in the earning capacity of immigrants and an equally dramatic increase in unemployment. Unemployment is higher among "immigrant youth" than among "Swedish" youth, and it is also considerably higher among the children of refugees as compared with children of labour migrants (Ålund 1997). These trends in the Swedish labour market are worrying and warrant concerned reflection. In Sweden, as in the US and Canada, a "structural" rather than a "cultural" pluralism has developed (Porter 1968, Gordon 1970, Ålund 1985). However, explanations for the inequality, differences and incongruities between Swedes and immigrants still tend to refer to cultural factors (Ålund and Schierup 1991, Ålund 1997).

In this way, multiculturalism can also be understood as a way of ranking different cultures - vertically - towards a societal split with different types of citizens, some of whom can be said to be more equal than others, at least with regard to the labour market. Such an order is based, among other things, on "culture" being understood as something unchangeable and constant, which can result in people being sorted "into cultures and cultures into places", and where 
“"place' may be a division of labour or of territory or both" (Feuchtwang 1990:4); ethnic entrepreneurship is part of this process.

\section{References}

Bengtsson, T. (1999) “Kurs gav dem jobb”, Dagens Nyheter, Vol. 25, No. 2,

\section{pp.4.}

Castles, S. and Miller, M.J. (1993) The Age of Migration, Basingstoke, Macmillan.

Castles, S. et al. (1984) Here for Good: Western Europe's New Ethnic Minorities, London and Sydney, Pluto Press.

Cohen, R. (1987) The New Helots: Migrants in the International Division of Labour, Aldershot, Avebury.

Collins, J., Gibson, K., Alcorso, C., Castles, S., and Tait, D. (1995) A Shop Full of Dreams; Ethnic Small Business in Australia, Leichhardt, Pluto Press,

Ekberg, J. (1994) "Economic progress of immigrants in Sweden from 1970 to 1990. A longitudinal study", Scandinavian journal for Social Welfare, No. 3/94, pp. $148-157$

Erikson R. and Jonsson, J.O. (eds), Sorteringen i Skolan. Studier av snedrekrytering och utbildningens konsekvenser, Stockholm, Carlssons.

Eyrumlu, R. (1992) Turkar möter Sverige, Stockholm, Carlssons.

Feuchtwang, S. (1990) "Racism; Territoriality and Ethnocentricity", in Alrick X and Feuchtwang S. (eds), Antiracist Strategies, Aldershot, Avebury.

Giddens, A. (1991) Modernity and Self-Identity, Oxford, Polity. 
Hjarnö, J. (1987) Invandrere fra Tyrkiet i Stockholm og Kobenhavn, Esbjerg, Sydjysk Universitetsforlag.

Jönsson, D. (2000) “Alla riktar de blickarna mot Europa”, Dagens Nyheter, 19 May, 2000.

Kloosterman R., van der Leun, J. and Rath, J. (1998) “Across the border: immigrants' economic opportunities, social capital and informal business activities", Journal of Ethnic and Migration Studies, Vol. 24, No. 2, pp. 249268.

Knocke, W. (1991) “Invandrade kvinnor - vad är 'problemet'?” Kvinnovetenskaplig Tidsskrift, Nr. 3/91, pp. 4-15.

Leiniö, T.-L. (1994) “Invandrarungdomars etablering”, SOU, 1994:73, pp. 313347.

Najib, A. (1995) “Inte bara pizzerior och kiosker", Invandrare \& Minoriteter, No 3/95 pp. 2-6.

Najib, A. (1999) “Invandrare som företagare - en bortglömd resurs? Föreläsning i serien "Forskare om entreprenörskap \& småföretag", Esbri, Institut för entreprenörskaps- oh småföretagsforskning.

Porter, J. (1968) The Vertical Mosaic: Analyses of Social Class and Power in Canada, Toronto, Univ. of Toronto Press.

Rex, J. (1995) "Ethnic Identity and the Nation State: the Political Sociology of Multi-Cultural Society”, Social Identities, Vol. 1, No. 1, pp. 21-35.

Sassen, S. (1996) "Place and work in the global informal economy", First International Metropolis Conference, Milan, 13-15 November 1996.

Schierup, C.U. and Paulsson, S. (eds) (1994) Arbetets etniska delning: Studier från en svensk bilindustri, Stockholm, Carlssons. 
Similä, M. (1994) “Andra generationens invandrare i den svenska skolan”, in Erikson R. and Jonsson, J.O. (eds), Sorteringen i skolan, Stockholm, Carlssons.

Stasiulis, D. and Bhakan, A. (1996) "Negotiating the Citizenship Labyrinth: Obstacles to and Empowerment Strategies of Migrant Women Workers", Paper for a Conference on Women and Citizenship, The University of Greenwich, London (16-18 July).

Turner, B.S. (1990) “Outline of a Theory of Citizenship”, Sociology, Vol. 24, No. 2, pp. 189-217.

Wadensjö, E. (1995), Ett delat Sverige; Invandrarna på svensk arbetsmarknad under 1990-talet, Stockholm, Projektansökan till Arbetsmiljöfonden.

Waldinger, R. (1996) Still the Promised City? African-Americans and New Immigrants in Postindustrial New York, Cambridge, Mass., and London, Harvard University Press.

Werbner, P. (1999) “What colour 'success'? Distorting value in studies of ethnic entrepreneurship", The Sociological Review, Vol. 47, No. 3, pp. 548580.

Ålund, A. (1985) Skyddsmurar; etnicitet och klass i invandrarsammanhang, Stockholm, Liber.

Ålund, A. (1991) Lilla Juga; Etnicitet, familj och kvinnliga nätverk $i$ kulturbrytningars tid, Stockholm, Carlssons.

Ålund, A. (1997) Multikultiungdom. Kön, etnicitet, identitet, Lund, Studentlitteratur.

Ålund, A. and Schierup, C.U. (1991) Paradoxes of Multiculturalism. Essays on Swedish Society, Aldershot, Avebury. 